\title{
Ictal Cortical Blindness with Permanent Visual Loss
}

\author{
Michael S. Aldrich, Chris W. Vanderzant, Anthony G. Alessi, Bassel Abou-Khalil, and \\ J. Chris Sackellares \\ Department of Neurology, University of Michigan Medical Center, Ann Arbor, Michigan, U.S.A.
}

\begin{abstract}
Summary: Cortical blindness is rarely an ictal manifestation. We report the case of a man who developed transient cortical blindness followed by permanent visual deficits during repeated partial seizures. Intermittent visual impairment began at age 14 years. After he had the first generalized seizure at age 28 years, neurologic, ophthalmologic, angiographic, and brain computed tomographic (CT) examinations were normal. Several EEGs showed almost continuous biposterior spike-waves. Over the next several years, frequent partial seizures were associated with transient visual loss and left body twitching or par-
\end{abstract}

esthesias. When he was 32 , transient blindness occurred during several days of repeated occipital seizures. Permanent left homonymous hemianopia, right homonymous central scotoma, dyschromatopsia, and altered stereopsis followed these seizures. Brain CT demonstrated a new right occipital lesion. Partial seizures arising posteriorly may cause transient cortical blindness and result in permanent visual deficits. Key Words: Epilepsy-Partial seizures-Occipital lobe-Blindness-Status epilepticusElectroencephalography.
Cortical blindness is an unusual manifestation of epilepsy. Although children, and less commonly adults, may transiently be blind after generalized tonic-clonic seizures (Ashby and Stephenson, 1903; Pritchard, 1918; Olurin, 1972; Kosnik et al., 1976; Sadeh et al., 1983), permanent postictal blindness is rare (Radhakrishnan et al., 1979; Sadeh et al., 1983). Ictal blindness has been reported in children and adults (Russel and Whitty, 1955; Strauss, 1963; Kooi, 1970; Huott et al., 1974; Engel et al., 1978; Gastaut, 1982; Olivier et al., 1982), but permanent visual loss following partial seizures has not been described except in occasional patients with preexisting visual deficits (Russel and Whitty, 1955; Kooi, 1970). We report a man with many years of episodic visual disturbance who developed transient cortical blindness during repeated partial seizures, followed by a permanent left homonymous hemianopia, right homonymous central scotoma, dyschromatopsia, and altered stereopsis.

Received July 1986; revision accepted April 1988

This work was presented in part at the American EEG Society meetings, Salt Lake City. Utah. September 1984, and published in Electroencephalogr Clin Neurophysiol 1985;61:37P.

Address correspondence and reprint requests to Dr. M. S. Aldrich at Department of Neurology, 1500 East Medical Center Dr., 1920/0316 Taubman Center. Ann Arbor. MI 48109-0316. U.S.A.

\section{CASE REPORT}

A 32-year-old, right-handed man had frequent episodes of visual disturbance without headache beginning at age 14 years. Depth perception would become distorted and objects appeared "wavy" or "faded out." Occasional biposterior headaches were not associated with visual disturbance. There was no personal or family history of migraine.

At age 28 years, first a generalized tonic-clonic seizure occurred, followed by frequent partial seizures associated with twitching movements or paresthesias of the left arm or left leg. EEG showed nearly continuous bioccipital and right posterior temporal spikes and spike-and-slow-wave complexes. Neurologic and ophthalmologic examinations were normal, including visual acuity, visual fields by perimetry, and color vision. Brain computed tomography (CT), cerebrospinal fluid (CSF) analysis, and carotid and vertebral angiography were normal.

Transient visual difficulties and partial motor seizures continued despite treatment with phenytoin (PHT), phenobarbital (PB), primidone (PRM), and valproate (VPA), singly or in combination. He had moments of almost total blindness and episodes of darkened peripheral vision around a central white spot. Reading was often difficult because print "ran together" or "disappeared." During one examina- 
tion, his vision suddenly worsened, and he briefly had only light perception. Repeated EEGs all showed nearly continuous biposterior epileptiform activity (Fig. 1) unaffected by eye movements or reading. Pattern-reversal visual evoked potentials were normal.

When the patient was 32, PRM dosage was tapered owing to complaints of sedation; PHT and VPA were continued. Ten days after PRM was discontinued, a right posterior headache developed associated with a 45-min hallucination of "red flashing lights" in the left hemifield. The following morning, a generalized tonic-clonic seizure occurred and he came to the hospital. When first examined, he had repeated partial seizures with twitching of the right arm and jerking of the head and eyes to the left without altered consciousness or disorientation. A dense left homonymous hemianopia and impaired voluntary gaze to the right were apparent. Vision was limited to finger counting in the right upper quadrant and possible hand motion and light perception in the right lower quadrant. Intermittently, his eyes deviated tonically to the right side. Serum electrolytes and CSF analysis were normal. Serum PHT level was $16.5 \mu \mathrm{g} / \mathrm{ml}$ and VPA level was 31.7 $\mu \mathrm{g} / \mathrm{ml}$.

Repeated partial seizures occurred over the next 6 days, but there were no additional generalized seizures. EEG with closed circuit television monitoring on the first hospital day recorded many seizures of 40-150-s duration during which head and eyes deviated to the left with clonic movements of the left arm and leg. Ictal EEGs showed rhythmic repetitive sharp waves and spikes beginning over the right posterior quadrant and spreading to involve both hemispheres. Interictal EEGs demonstrated frequent bioccipital and left posterior temporal spikes and bursts of rhythmic slow waves. Videotaped examinations, both ictal and interictal, documented blindness with inability to count fingers, see hand motion, or identify objects or familiar faces.

Partial seizures continued despite oral carbamazepine (CBZ) and intravenous (i.v.) PHT and PB. Intubation and continuous i.v. diazepam were required on the second hospital day to control the seizures. There were no episodes of hypoxia or hypotension. After extubation, on the seventh day, he had confusion, right gaze preference, sensory extinction on the left, and occasional hallucinations of "cartoon figures." Repeated examinations demonstrated visual acuity $<20 / 400$ O.U., left homonymous hemianopia, and intermittent ability to count fingers in the right visual field. He could not read the Ishihara color control card. Brain CT on the 9th day and radionuclide cerebral blood flow scan on the eighteenth day were normal. By the 18th hospital day, he was alert and oriented. Repeat EEG showed frequent biposterior spikes and spikewaves with right posterior temporal emphasis.

Two months after discharge, he still had simple partial seizures with left-sided jerking, and white

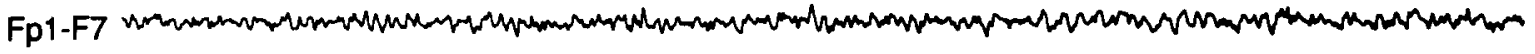

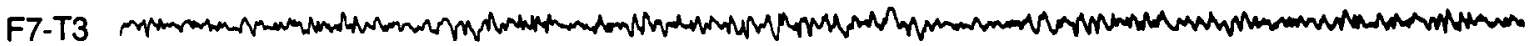

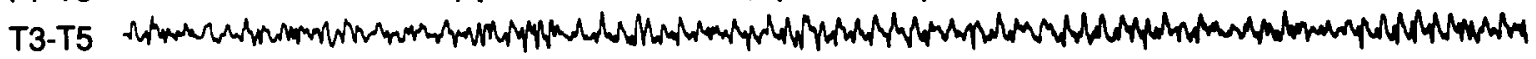

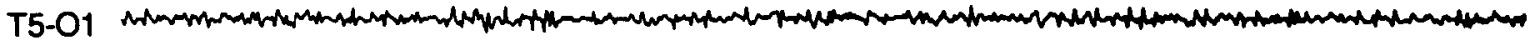

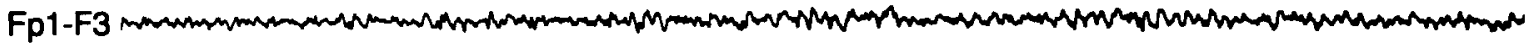

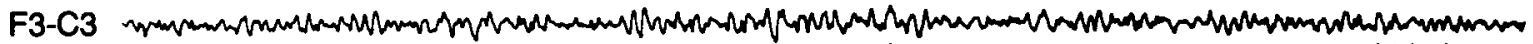

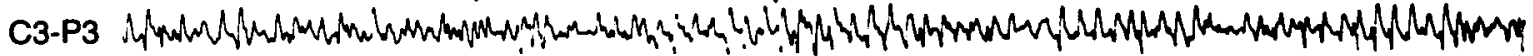

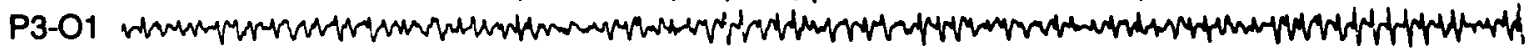

FP2-F4 m

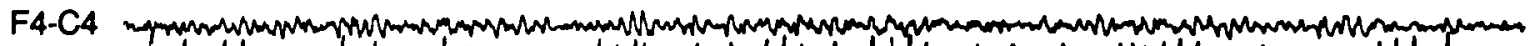

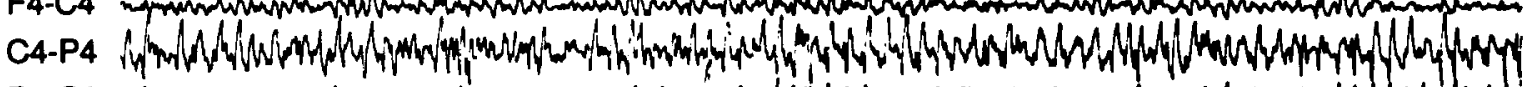

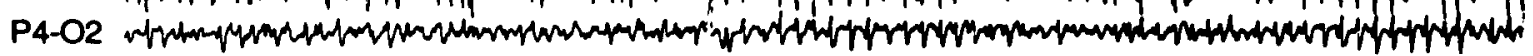

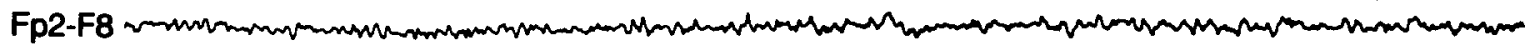

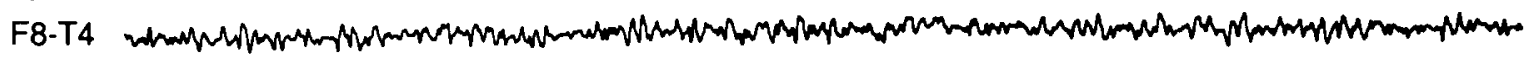

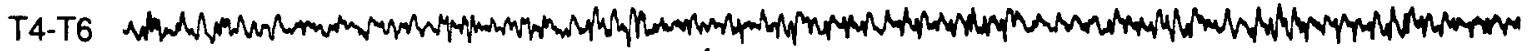

T6-O2 J sour

FIG. 1. Ictal EEG showing continuous serial spikes and spike-and-slow-waves over both posterior regions. 
spots appeared frequently in the left visual field. A dense left homonymous hemianopia persisted, visual acuity was 20/60 O.U., and stereopsis was poor. He could read the Ishihara color control card but none of the 10 test cards. Repeat brain CT showed a right medial occipital lucency (Fig. 2).

Two years later, seizure control was improved with a regimen of PHT, VPA, and PB. There were no motor or sensory symptoms, but involuntary jerking of the eyes occurred occasionally. Visual acuity was 20/40 O.U. Perimetry demonstrated a complete left homonymous hemianopia and a small homonymous right central scotoma (Fig. 3). Color vision was unchanged. EEG showed frequent spikes and spike-waves occurring mainly over the left parietal-occipital and posterior temporal regions.

\section{DISCUSSION}

This man's epilepsy is unusual because (a) transient blindness occurred both ictally and postictally; (b) fixed visual deficits, including dyschromatopsia, occurred after protracted occipital seizures; and (c) CT evidence of right occipital encephalomalacia eventually developed. Acquired dyschromatopsia is a rare phenomenon which is usually caused by bilateral lesions involving the inferior occipital regions (Meadows, 1974; Green and Lessell, 1977). Also striking was the high incidence of biposterior epileptiform activity on every EEG obtained over several years.

The onset of permanent left homonymous hemianopia and right homonymous superior central scotoma coincided with the prolonged period of

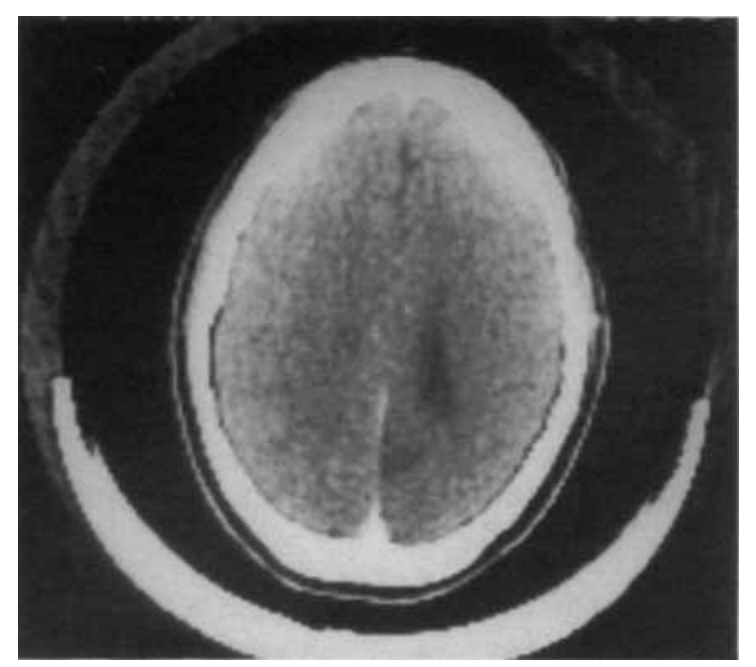

FIG. 2. Brain computed tomography, 2 months after discharge from hospital, shows an area of right medial occipital encephalomalacia. partial seizures. Although up to $20 \%$ of epileptic patients with occipital EEG foci may have visual field deficits (Ludwig and Marsan, 1975), these deficits usually predate the seizures. Gastaut (1982) emphasized the benign character of partial epilepsy of childhood associated with occipital spike-waves: 92\% of cases had complete remission of seizures by age 19 years. A benign course was also reported in four adolescents with seizures, basilar migraine, and occipital spike-waves (Camfield et al., 1978). Our report documents that such cases are not limited to childhood and that the prognosis is not uniformly benign.

Our patient shows some clinical similarities to patients with the syndrome of mitochondrial myopathy, encephalopathy, lactic acidosis, and strokelike episodes (MELAS) (Pavlakis et al., 1984). A variant of this syndrome has been reported in which mitochondrial encephalopathy and strokes are associated with migraine headaches and occipital seizures (Dvorkin et al., 1987), and several of the patients developed permanent hemianopias or cortical blindness. Although our patient did not have headaches with his episodes of visual disturbance, or the short stature typical of MELAS syndrome, his condition may be related to these syndromes. We did not measure serum or CSF lactic acid and did not obtain a muscle biopsy to look for ragged red fibers.

The cause of the permanent visual loss cannot be stated with certainty. In two reported cases of permanent blindness following generalized seizures, blindness was attributed to the effects of anoxia (Radhakrishnan et al., 1979; Sadeh et al., 1983). Our patient had no evidence of an anoxic or hypotensive episode and had only one generalized tonic-clonic seizure. Although infarction resulting from vasospasm or vascular occlusion may have induced the prolonged partial seizures, the previously normal angiogram and the absence of migraine or other risk factors for cerebrovascular disease make this possibility unlikely. Furthermore, evidence of infarction would usually be apparent on brain CT by the ninth hospital day, yet CT of our patient was normal at that time. Not until 2 months later did the CT lesion appear.

That the repeated occipital seizures induced irreversible cerebral damage from metabolic compromise is more likely. Primate studies have shown that prolonged seizures can produce neuronal damage independent of the effects of hypotension, acidosis, and hypoxia (Meldrum and Brierly, 1973). Moreover, a preexisting epileptogenic focus may have rendered the patient's occipital cortex more vulnerable to the deleterious metabolic effects of repeated seizures.

Although the ictal manifestations of epilepsy are 


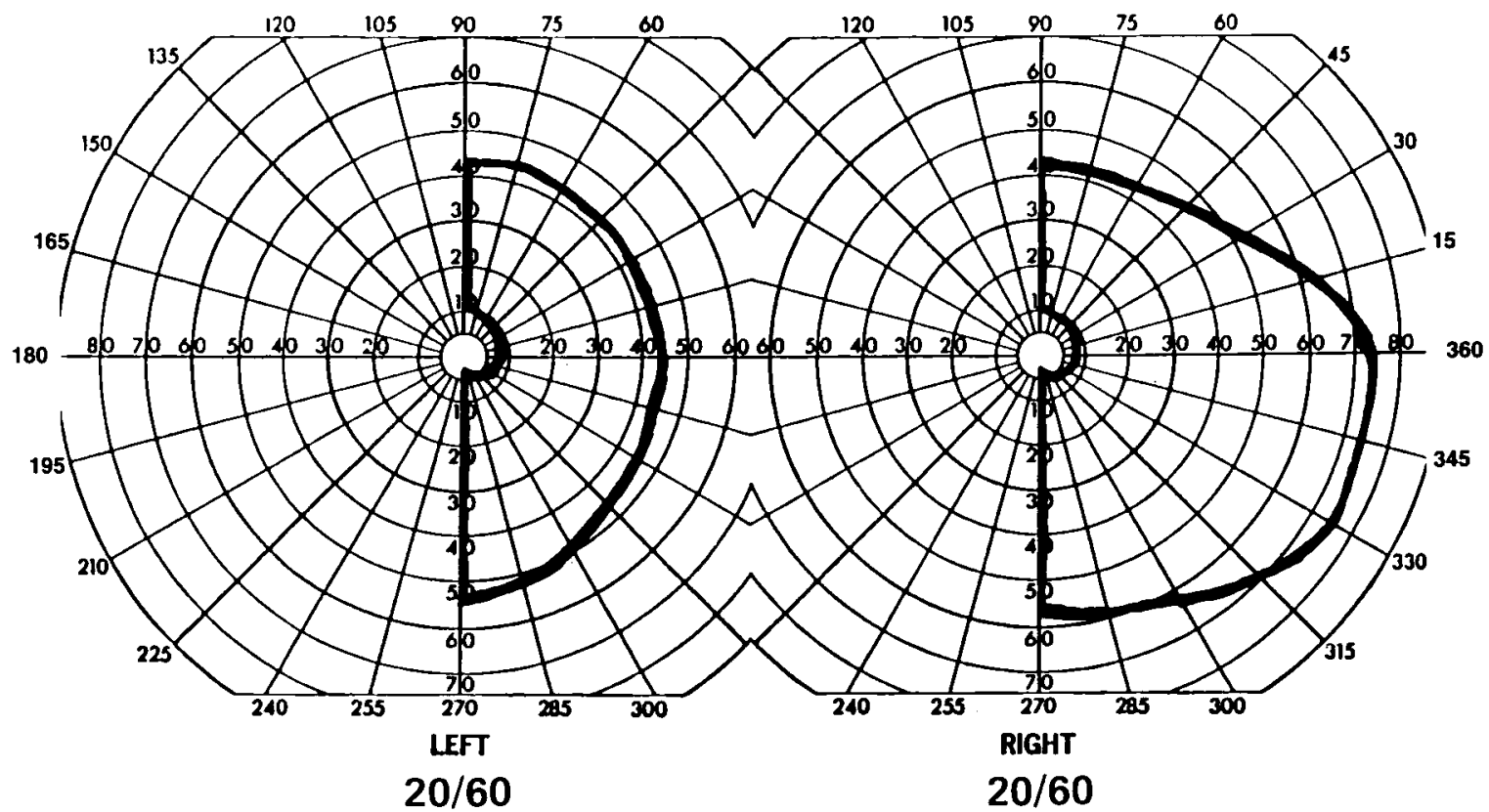

\section{$V_{1 e}$}

FIG. 3. Visual fields 2 years after discharge from hospital, showing a left homonymous hemianopia and right central scotoma.

usually brief, clinical and EEG data suggest that our patient's episodes of prolonged but reversible visual disturbance occurring during 18 years were almost continuous simple partial seizures involving occipital cortex. Our report underscores the fact that visual hallucinations, reading impairment, or cortical blindness may all be manifestations of epileptic seizures. Occipital seizures should be considered in the differential diagnosis of any patient with intermittent or fluctuating visual complaints. The potential for partial seizures to lead to permanent cerebral damage extending beyond the region of the original epileptogenic focus emphasizes the need for prompt treatment of frequent or protracted partial seizures.

\section{REFERENCES}

Ashby $\mathrm{H}$, Stephenson S. Acute amaurosis following infantile convulsions. Lancet 1903:1:1294-6.

Camfield PR, Metrakos K, Andermann F. Basilar migraine, seizures, and severe epileptiform EEG abnormalities. Neurology $1978 ; 28: 584-8$.

Dvorkin GS, Andermann F, Carpenter S, et al. Classical migraine, intractable epilepsy and multiple strokes: a syndrome related to mitochondrial encephalomyopathy. In: Andermann F, Lugaresi E, eds. Migraine and epilepsy. Boston: Butterworths 1987:203-32.

Engel J, Ludwig BI, Fetell M. Prolonged partial complex status epilepticus: EEG and behavioral observations. Neurology 1978:28:863-9.

Gastaut H. A new type of epilepsy: benign partial epilepsy of childhood with occipital spike-waves. Clin Electroencephalogr 1982:13;13-22.

Green GJ, Lessell S. Acquired cerebral dyschromatopsia. Arch Ophthalmol 1977;95:121-8.

Huott AD, Madison DS, Niedermeyer E. Occipital lobe epilepsy. A clinical and electroencephalographic study. Eur Neurol 1974;11:325-39.

Kooi K. Episodic blindness as a late effect of head trauma. Electrophysiological study of 3 cases. Neurology 1970;20:569-73.

Kosnik E, Paulson GW, Laguna JF. Postictal blindness. Neurology 1976;26:248-50

Ludwig BI, Ajmone-Marsan C. Clinical ictal patterns in epileptic patients with occipital electroencephalographic foci. Neurology 1975:25:463-71.

Meadows JC. Disturbed perception of colours associated with localized cerebral lesions. Brain 1974;97:615-32.

Meldrum BS, Brierly JB. Prolonged epileptic seizures in primates. Arch Neurol 1973;28:10-7.

Olivier A, Gloor P, Andermann F, Ives J. Occipitotemporal epilepsy studied with stereotaxically implanted depth electrodes and successfully treated by temporal resection. $A n n$ Neurol 1982;11:428-32.

Olurin O. Cortical blindness following convulsions and fever in Nigerian children. Surv Ophthalmol 1972;16:341-2.

Pavlakis SG, Phillips PC. DiMauro S. et al. Mitochondrial my. opathy, encephalopathy, lactic acidosis, and stroke-like episodes: a distinctive clinical syndrome. Ann Neurol 1984; 16:481-8.

Pritchard E. Cases of amaurosis following violent convulsions. Proc Soc R Med 1918:11:1-2.

Radhakrishnan K, Razdan S, Chopra JS. Postictal blindness. Neurology (India) 1979;27:196-8.

Russel WR. Whitty CWM. Studies in traumatic epilepsy. 3. Visual fits. $J$ Neurol Neurosurg Psychiatry 1955;18:79-96.

Sadeh M. Goldhammer Y, Kuritsky A. Postictal blindness in adults. J Neurol Neurosurg Psychiatry 1983:46:566-9. 
Strauss H. Paroxysmal blindness. Electroencephalogr Clin Neurophysiol 1963;15:921.

\section{RÉSUMÉ}

La cécité corticale est rarement une manifestation critique. Les auteurs rapportent l'observation d'un homme qui a présenté une cécité cortical transitoire suivie de déficits visuels permanents à l'occasion de crises partielles répétées. Les épisodes de gêne visuelle intermittente ont commencé à l'âge de 14 ans. Après une première crise généralisée à l’âge de 28 ans, un bilan complémentaire comprenant examen neurologique, ophtalmologique, angiographie et scannographie cérébrale s'est révélé normal. Les EEG successifs ont montré l'exsistence de pointesondes bipostérieures pratiquement continues. Pendant les années suivantes, le patient a présenté de nombreuses crises partielles avec perte transitoire de la vision et secousses ou paresthésies de l'hémicorps gauche. A l'âge de 32 ans, une cécité transitoire se produisit à l'occasion de crises occipitales répétées pendant plusieurs jours. Après ces crises, on a constaté la persistance d'une hémianopsie homonyme gauche, d'une scotome central homonyme droit, d'une dyschromatopsie et d'une altération de la vision stéréoscopique. La scannographie cérébrale a mis en évidence une lésion occipitale droite récente. Les crises partielles postérieures peuvent entraîner une cécité corticale transitoire et évoluer vers des déficits visuels permanents.

(P. Genton, Marseille)

\section{RESUMEN}

La ceguera cortical es una rara manifestación de los ataques. Se publica el caso de un hombre que desarrolló ceguera cortical transitoria seguida de un déficit visual permanente durante ataques parciales repetidos. Los ataques de trastorno visual intermitente empezaron a la edad de 14 años. Después de un primer ataque generalizado a la edad de 28 años los estudios neurológicos, oftalmológicos, angiográficos y de tomografía computarizada fueron normales. Varios EEGs mostraron complejos biposteriores punta-onda, prácticamente continuos. Durante los siguientes años ataques parciales frecuentes se asociaron a pérdida de visión transitoria y parestesias o movimientos en el lado izquierdo de su cuerpo. A la edad de 32 años tuvo una ceguera transitoria durante varios dias de ataques occipitales repetidos. Estos ataques se siguieron de una hemianopsia homónima izquierda permanente, escotoma central homónimo derecho, discromatopsia y estereopsia alterada. La CT cerebral mostró una lesión occipital derecha nueva. Los ataques parciales que se originan en regiones posteriores pueden causar ceguera cortical transitoria y producir déficits permanentes.

(A. Portera-Sánchez, Madrid)

\section{ZUSAMMENFASSUNG}

Kortikale Blindheit gilt als seltenes Anfallssymptom. Wir berichten über einen Patienten mit transienter kortikaler Blindheit, die von bleibender Vissusstörung gefolgt wurde. Eine intermittierende visuelle Verschlechterung stellte sich mit 14 Jahren ein. Nach einem ersten generalisierten Anfall im Alter von 28 Jahren fanden sich neurologisch, ophthalmologisch, angio- und computertomographischein Normalbefunde. Mehrere EEG's zeigten kontinuierliche biposteriore spike-wave. In den folgenden Jahren waren häufige Partialanfälle mit vorübergehendem Visusverlust und linksseitigen Körperzuckungen und Paraesthesien verbunden. Mit 32 Jahren trat eine vorübergehende Blindheit während mehrerer Tage bei wiederholten Anfällen auf. Darauf stellte sich eine homonyme Hemianopsie links, ein homonymes Zentralskotum rechts, Dyschromasie and verändertes Stereosehen ein. Das CT zeigte eine frische occipitale Laesion rechts. Partialanfälle mit occipitalem Ursprung können vorübergehende kortikale Blindheit verursachen und in eine permanente Visuseinbuße münden.

(C. G. Lipinski, Heidelberg/Neckargemünd) 